Ganadian Revue

Journal of canadienne de
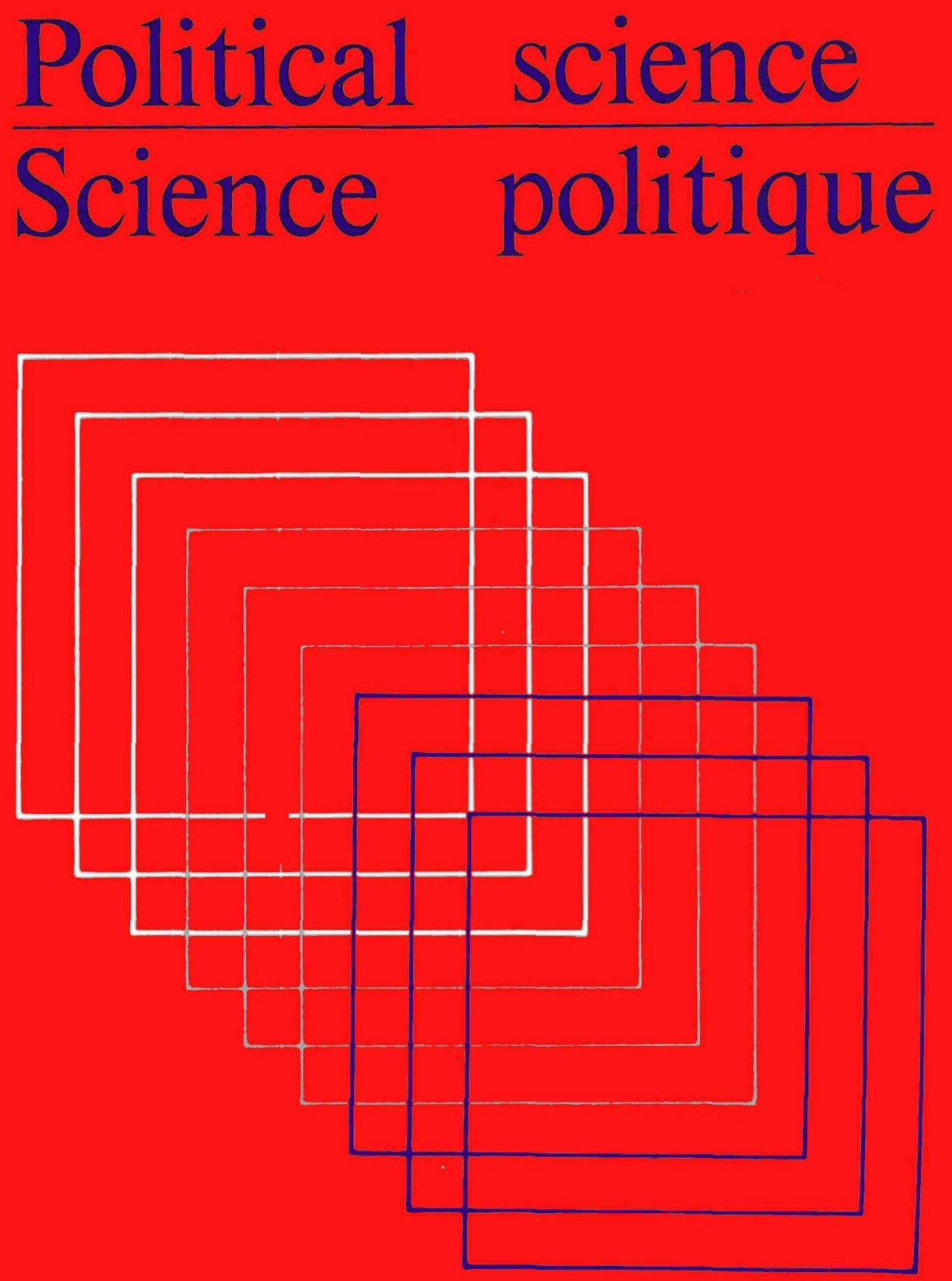

June 1991 juin XXIV:2 


\section{Editorial Board / Comité de rédaction}

Roger Gibbins (Calgary), co-editor Carol Prager (Calgary), review editor

Thomas Flanagan (Calgary), assistant editor
Stéphane Dion (Montréal), codirecteur Guy Laforest (Laval),

secrétaire à la rédaction et responsable des recensions

John McMenemy, managing editor/directeur de la gestion, Wilfrid Laurier University

Advisory Board / Conseil Consultatif

Gérald Bernier (Montréal)

David Braybrooke (Dalhousie)

Alan C. Cairns (British Columbia)

Réjean Landry (Laval)

Jane Jenson (Carleton)

Alexander MacLeod (UQAM)

Mildred Schwartz (Illinois)

The Journal acknowledges with gratitude the generous assistance of the Social Sciences and Humanities Research Council of Canada. / La Revue tient à remercier le Conseil de recherches en sciences humaines du Canada pour la généreuse subvention qu'il a bien voulu lui accorder.

INDEXED IN / INDEXÉE AU: International Political Science Abstracts/Documentation politique internationale; ABC POL SCI (Advance Bibliography of Contents: Political Science and Government); Historical Abstracts; America: History and Life; Political Science Abstracts; Périodex: index analytique de périodiques de langue française; Sociological Abstracts; United States Political Science Documents; Arts \& Humanities Citation Index (A\&HCI); Current Contents/Arts \& Humanities; PAIS Bulletin and PAIS Foreign Language Index; Canadian Periodical Index/Index de périodiques canadiens; Canadian Magazine Index and available on-line in the Canadian Business and Current Affairs Database; Index to Canadian Legal Periodical Literature (partial/partiel); Indian Book Review Digest (partial/partiel); International Political Science Information Service; IBZ (Internationale Bibliographie der Zeitschriftenliteratur); IBR (Internationale Bibliographie der Rezensionen).

Membership in the Canadian Political Science Association and/or the Société québécoise de science politique includes a subscription to the Journal. Institutional subscriptions (which do not include membership privileges) and institutional memberships are also available. The Journal may be obtained in paper and fiche. / La cotisation versée à l'Association canadienne de science politique et/ou à La société québécoise de science politique donne droit à un abonnement à $L a$ Revue. Des abonnements déstinés aux institutions (qui ne donnent pas droit aux privilèges réservés aux membres) ainsi que des adhésions institutionnels sont également offerts. Vous pouvez recevoir $\mathrm{La}$ Revue sous la forme d'une revue et de micro-fiches.

Business correspondence should be sent to the Administrator, Canadian Political Science Association, Suite 205, 1 Stewart Street, Ottawa, Ontario K1N 6H7 (e-mail: CPSCC@ UOTTAWA; fax: 1-613-230-2746). / Prière d'adresser toute communication de caractère commercial à l'Administrateur, Association canadienne de science politique, Bureau 205, 1, rue Stewart, Ottawa, Ontario K1N 6H7 (adresse électronique : CPSCC@UOTTAWA; télécopieur: 1-613-230-2746).

The headquarters of the Canadian Political Science Association is Suite 205, 1 Stewart Street, Ottawa, Ontario K1N 6H7./ Le siège social de l'Association canadienne de science politique est Bureau 205, 1, rue Stewart, Ottawa, Ontario K1N 6H7. Le siège social de la Société québécoise de science politique est à / The headquarters of the Société québécoise de science politique is at the Université du Québec à Montréal, Montréal, Québec H3C 3P8.

(c) Canadian Political Science Association (l'Association canadienne de science politique) and/et la Société québécoise de science politique 1991

Published by / Publiée par Wilfrid Laurier University Press for/pour the Canadian Political Science Association ('Association canadienne de science politique) and/et la Société québécoise de science politique 


\section{Contents / Sommaire}

Foucault et l'Iran: À propos du désir de révolution LAWRENCE OLIVIER et SYLVAIN LABBÉ 219

Party Elites, Voters and Political Attitudes: Testing Three Explanations for Mass-Elite Differences

IAN MCALLISTER 237

Intergovernmental Relations in Canada: An Institutional Analysis MARTIN PAINTER 269

The Charter in the Supreme Court of Canada: The Importance of Which Judges Hear an Appeal ANDREW D. HEARD 289

Why Property Rights Were Excluded from the Canadian Charter of Rights and Freedoms

ALEXANDER ALVARO 309

Parties and Candidate Selection in the 1988 Canadian General Election LYNDA ERICKSON and R. K. CARTY 331

Local Constraints on Provincial Initiative in a Dynamic Context: The Case of Property Tax Reform in Ontario FRANCES FRISKEN 351

Recensions / Reviews 379 